\title{
Appropriate Solution for Poor Shelf Life Problem in Rainy Season Guava (Psidium guajava) var.'L-49'
}

\author{
Swosti Debapriya Behera ${ }^{1}$, Sanjay Pathak $^{2}$ and Nishita Pathak ${ }^{1}$ \\ ${ }^{1}$ Department of Horticulture, Assam Agricultural University, Jorhat-785013, Assam, India \\ ${ }^{2}$ Department of Horticulture, Narendra Deva University of Agriculture and Technology, \\ Faizabad, Uttar Pradesh (224 229), India
}

Corresponding author

\begin{tabular}{|c|c|}
\hline & A B S T R A C T \\
\hline $\begin{array}{l}\text { Ambe bahar, Shelf } \\
\text { life, Physiological } \\
\text { weight loss, } \\
\text { Calcium chloride, } \\
\text { Polythene bag }\end{array}$ & \multirow{3}{*}{$\begin{array}{l}\text { Shelf life of rainy season or Ambe bahar guava is very poor due to uncongenial } \\
\text { atmospheric condition during fruiting period. Warm and humid conditions cause the fruits } \\
\text { to be infected by insects and disease causing organisms along with loss in weight. A detail } \\
\text { study of physiological weight loss during storage of guava fruits was carried out after } \\
\text { various pre harvest treatments at Narendra Deva University of Agriculture and } \\
\text { Technology, Faizabad, Uttar Pradesh during } 2015-16 \text {. The guava fruits were treated with } \\
\text { nine pre harvest treatments including spraying of } \mathrm{CaCl}_{2} 2 \%, \mathrm{CaSO}_{4} 2 \% \text {, Bagging with } \\
\text { polythene and brown paper, } \mathrm{CaCl}_{2} 2 \%+\text { polythene bag, } \mathrm{CaCl}_{2} 2 \%+\text { brown paper bag, } \\
\mathrm{CaSO}_{4} 2 \%+\text { polythene bag, } \mathrm{CaSO}_{4} 2 \% \text { brown paper bag and Control. The interaction } \\
\text { effects of pre harvest treatments and duration of storage on physiological weight loss of } \\
\text { fruits were studied. Physiological weight loss value of all treatments was found } \\
\text { significantly higher than control. The minimum PLW of } 0.69 \% \text { with the maximum shelf } \\
\text { life period of } 9 \text { days was recorded in combined treatment of calcium chloride and } \\
\text { polythene bag. }\end{array}$} \\
\hline Article Info & \\
\hline $\begin{array}{l}\text { Accepted: } \\
\text { 15 June } 2018 \\
\text { Available Online: } \\
\text { 10 July } 2018\end{array}$ & \\
\hline
\end{tabular}

\section{Introduction}

Guava (Psidium guajava Linn.) is known as poor man's apple due to it's easy availability. It is a very important fruit because of it's high nutritious value. Allahbad district in Uttar Pradesh has reputation of growing the best quality guava in the world. Among three fruiting seasons Mrig bahar guava is the best in quality. Ambe bahar guava grown in rainy season is the poorest. The fruits harvested in this season are insipid, watery and attacked mostly by diseases and pests. Keeping quality of ambe bahar guava fruits is very poor. Hence fruits in this season are removed by crop regulation or bahar treatment methods which hamper the annual production of guava.

Several attempts have been carried out by various research workers in different countries to increase shelf life in ambe bahar guava fruits. Singh et al., (1993) reported that the $\mathrm{Ca}^{+2}$ treatments with calcium nitrate (1 and 2 $\%)$ and Calcium chloride (0.6 and 1.2\%) 
sprayed at 20 days and 10 days before harvest delayed ripening and had a favourable effect on the quality of the mango fruits cv. Dasheri during the storage. The pre harvest bagging in mango fruit cv. Apple improved the organoleptic quality, reduced weight loss and extended the shelf life of fruit at ambient temperature. Bagging treatment improves export quality and fetches better prices of fruits (Mathooko et al., 2011) Polythene bagging reduces damage in guava fruits particularly in rainy season and also improves fruit quality (Abbasi et al., 2014). Pre harvest foliar spray and bagging was done by Jakhar et al., (2014) which helped in reducing occurrence of black spotting and improving shelf life of mango fruits. Lu et al., (2014) reported that the effect of pre-harvest bagging treatments viz. on the storage characteristics of chilli pear fruits. They compared the performance of green transparent plastic bags and non-woven bags 60 days after flowering with non-bagged fruits. The rate of weight loss reduced by $30.05 \%, 23.30 \%, 20.23 \%$ in plastic, non-woven and non-bagged fruits, respectively.

\section{Materials and Methods}

\section{Experimental site}

The experiment was carried out at the guava orchard at Main Experiment station of Horticulture and Post Harvest Technology laboratory, Department of Post Harvest Technology, College of Horticulture and Forestry, Narendra Deva University of Agriculture and Technology, Kumarganj, Faizabad (U.P.), India during the kharif season of 2015-16.

\section{Materials for experiment}

Four year old bearing trees of guava cv. 'Lucknow-49', having uniform vigour and healthy fruits were selected for the study. The trees were spaced at $8 \mathrm{~m} \times 8 \mathrm{~m}$ spacing and uniform crop management practices were followed for all the plants.

\section{Treatment details}

The nine treatments of the experiment and their symbols are given in Table A.

These pre-harvest treatments were tried in randomized block design with three replications. Single tree was considered as an experimental unit. The nine treatments in each block were randomised. Altogether there were twenty seven trees. A total of 10 uniform sized fruits/tree present in all directions of tree canopy were selected and tagged for the study.

\section{Procedure for pre harvest treatments}

Bagging of fruits with various bags was done about 30 days before harvesting of fruits. Spraying of $\mathrm{CaCl}_{2} @ 2 \%$ alone in $\mathrm{T}_{1}$ and $\mathrm{CaSO}_{4} @ 2 \%$ alone in $\mathrm{T}_{4}$ were done twice at 15 and 30 days before harvest of fruits. Bagging of fruits with polythene bag alone in $\mathrm{T}_{7}$ and brown paper alone in $\mathrm{T}_{8}$ were done one month before harvest of fruits.

Bagging of fruits with polythene and brown paper bags was done in $T_{2}$ and $T_{3}$, respectively, in addition to single spraying with $\mathrm{CaCl}_{2} @ 2 \% 30$ days before harvesting. Similarly, in case of $\mathrm{T}_{5}$ and $\mathrm{T}_{6}$, bagging with polythene bag and brown paper bag was done, respectively, in addition to single spraying with $\mathrm{CaSO}_{4} @ 2 \%$. In case of treatments where spraying and bagging both were combined, the bagging was done immediately after the spraying.

\section{Bagging procedure}

Individual fruit was covered with brown paper bag or polythene bag and tied loosely by threads with stalk of fruits. 


\section{Spraying procedure}

To prepare spray solution of $2 \%$ concentration, $300 \mathrm{~g}$ either of calcium chloride or calcium sulphate depending on treatment were mixed thoroughly with 15 litre of clean water and the resulting spray solution was applied uniformly on the tree canopy in three plants of a particular treatment@ 5 litre per tree. The spray was done using a foot sprayer. Twin-20 was used as a surfactant (spreader and sticker) in spray solution @ $2 \mathrm{ml} /$ litre water.

\section{Harvesting, sorting and cleaning of fruits}

Fruits marked for study in all treatments were separately harvested by hand carefully to avoid any damage to fruits in morning hours on $1^{\text {st }}$ August, 2015.

The field heat of harvested fruits was reduced by showing to stream of hand pumped water and kept in shade for rinsing of water sticking to surface of fruits.

These fruits were transported from orchard to Post Harvest Technology laboratory with proper packing in CFB boxes to avoid physical damage including bruising.

Procedure for recording physiological weight loss during storage of fruits

Two fruits of each treatment were separately packed in polythene bags and bags were sealed properly. Six to eight small holes were made in polythene bags for air exchange.

All bags were marked as per treatments and then stored at ambient temperature in the laboratory of Post-Harvest Technology for further observations on changes during storage. The physical balance was used every day to record the weight during storage. The per cent physiological loss in weight was calculated by using following standard procedure (AOAC, 2000) mentioned below.

\section{Physiological loss in weight}

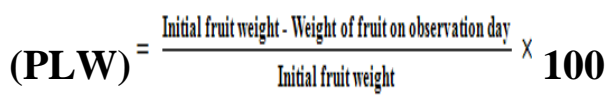

\section{Shelf life}

Percentage of Physiological weight loss was calculated regularly till the fruits became inedible and unmarketable. This storage duration was considered as shelf life of fruits.

\section{Results and Discussion}

The PLW per cent of guava fruits was increased progressively with the advancement of storage period at ambient temperature. All the treatments show significant difference in physiological weight loss. The minimum PLW $3.63 \%$ was recorded with the treatment of calcium chloride + polythene bag and the maximum PLW of $13.87 \%$ was recorded in control. However guava showed the shelf life upto 6 days with $10.25 \%$ PLW under ambient storage. During storage period starting from day2 to day 9 PLW data was recorded because maximum shelf life 9 days was found in the treatment of calcium chloride+ polythene bag. PLW\% differed significantly with days of storage. Minimum PLW (1.83\%) was recorded on $2^{\text {nd }}$ day and maximum PLW $(17.52 \%)$ was found on $9^{\text {th }}$ day.

Interaction effect of preharvest treatments and days of storage was found significant. Among the combinations the minimum PLW\% $(0.69 \%)$ was recorded with the treatment of calcium chloride + polythene bag on $2^{\text {nd }}$ day. Among the combination PLW\% of treatment with calcium chloride + polythene bag on day 3 (0.99), treatment with calcium chloride + brown paper bag on day2 (0.99), treatment of calcium chloride on day2 (1.13), calcium 
sulphate + polythene bag on day2 (1.12) were found statistically at par with treatment of calcium chloride + polythene bag on day 2 . PLW value of other treatments was recorded significantly higher than control.
Maximum shelf life was recorded with the treatment of calcium chloride+ polythene bag i.e. 9 days where as minimum was recorded in control i.e. 4 days (Table 1).

Table.A The nine treatments of the experiment and their symbols

\begin{tabular}{|c|c|c|}
\hline Sl. No. & Treatments & Symbol used \\
\hline $\mathbf{1 .}$ & $\mathrm{CaCl}_{2} @ 2 \%$ & $\mathrm{~T}_{1}$ \\
\hline $\mathbf{2 .}$ & $\mathrm{CaCl}_{2} @ 2 \%+$ Polythene bag & $\mathrm{T}_{2}$ \\
\hline $\mathbf{3 .}$ & $\mathrm{CaCl}_{2} @ 2 \%+$ Brown Paper bag & $\mathrm{T}_{3}$ \\
\hline $\mathbf{4 .}$ & $\mathrm{CaSo}_{4} @ 2 \%$ & $\mathrm{~T}_{4}$ \\
\hline $\mathbf{5}$ & $\mathrm{CaSo}_{4} @ 2 \%+$ Polythene bag & $\mathrm{T}_{5}$ \\
\hline $\mathbf{6 .}$ & $\mathrm{CaSo}_{4} @ 2 \%+$ Brown Paper bag & $\mathrm{T}_{6}$ \\
\hline $\mathbf{7 .}$ & Polythene bag & $\mathrm{T}_{7}$ \\
\hline $\mathbf{8 .}$ & Brown paper bag & $\mathrm{T}_{8}$ \\
\hline $\mathbf{9}$ & Control & $\mathrm{T}_{9}$ \\
\hline
\end{tabular}

Table.1 Effects (main and interaction) of pre-harvest treatments and storage duration on physiological loss in weight (\%) of fruits

\begin{tabular}{|c|c|c|c|c|c|c|c|c|c|}
\hline Treatments & Day2 & Day3 & Day4 & Day5 & Day6 & Day7 & Day8 & Day9 & Mean \\
\hline $\mathrm{T}_{1}-\mathrm{CaCl}_{2} 2 \%$ & 1.13 & 1.42 & 2.64 & 4.32 & 6.81 & 9.72 & 12.93 & 16.81 & 6.97 \\
\hline $\mathrm{T}_{2}-\mathrm{CaCl}_{2} 2 \%+$ Polythene bag & 0.69 & 0.99 & 1.52 & 2.34 & 4.21 & 6.53 & 9.51 & 13.24 & 3.63 \\
\hline $\begin{array}{l}\mathrm{T}_{3}-\mathrm{CaCl}_{2} 2 \%+\text { Brown Paper } \\
\text { bag }\end{array}$ & 0.99 & 1.21 & 1.92 & 3.04 & 5.12 & 7.64 & 11.24 & 15.31 & 5.81 \\
\hline $\mathrm{T}_{4}-\mathrm{CaSo}_{4} 2 \%$ & 1.23 & 1.51 & 2.73 & 4.41 & 6.92 & 9.78 & 13.12 & 17.00 & 7.09 \\
\hline $\mathrm{T}_{5}-\mathrm{CaSo}_{4} 2 \%+$ Polythene bag & 1.12 & 1.38 & 2.53 & 4.11 & 6.52 & 9.62 & 12.82 & 16.55 & 6.83 \\
\hline $\begin{array}{l}\mathrm{T}_{6}-\mathrm{CaSo}_{4} 2 \%+\text { Brown Paper } \\
\text { bag }\end{array}$ & 1.15 & 1.41 & 2.56 & 4.14 & 6.55 & 9.65 & 12.85 & 16.58 & 6.86 \\
\hline $\mathrm{T}_{7}$-Polythene bag & 1.17 & 1.43 & 2.58 & 4.16 & 6.57 & 9.67 & 12.88 & 16.76 & 6.90 \\
\hline $\mathrm{T}_{8}$ - Brown Paper bag & 2.23 & 2.44 & 3.59 & 5.17 & 7.58 & 10.68 & 13.89 & 17.77 & 7.92 \\
\hline $\mathrm{T}_{9}-$ Control & 2.52 & 4.67 & 7.77 & 11.26 & 14.96 & 18.96 & 23.16 & 27.66 & 13.87 \\
\hline $\mathrm{T}_{1}-\mathrm{CaCl}_{2} 2 \%$ & 1.13 & 1.42 & 2.64 & 4.32 & 6.81 & 9.72 & 12.93 & 16.81 & 6.97 \\
\hline \multicolumn{2}{|l|}{ Characters } & \multicolumn{3}{|c|}{ Treatments } & \multicolumn{2}{|c|}{ Days } & \multicolumn{3}{|c|}{ Treatments x Days } \\
\hline $\mathrm{SEm} \pm$ & & \multicolumn{3}{|c|}{0.09} & \multicolumn{2}{|c|}{0.08} & \multicolumn{3}{|c|}{$\mathbf{0 . 8 2}$} \\
\hline
\end{tabular}




\section{Effect of pre harvest treatments on physiological loss in weight of guava fruits during storage (\%)}

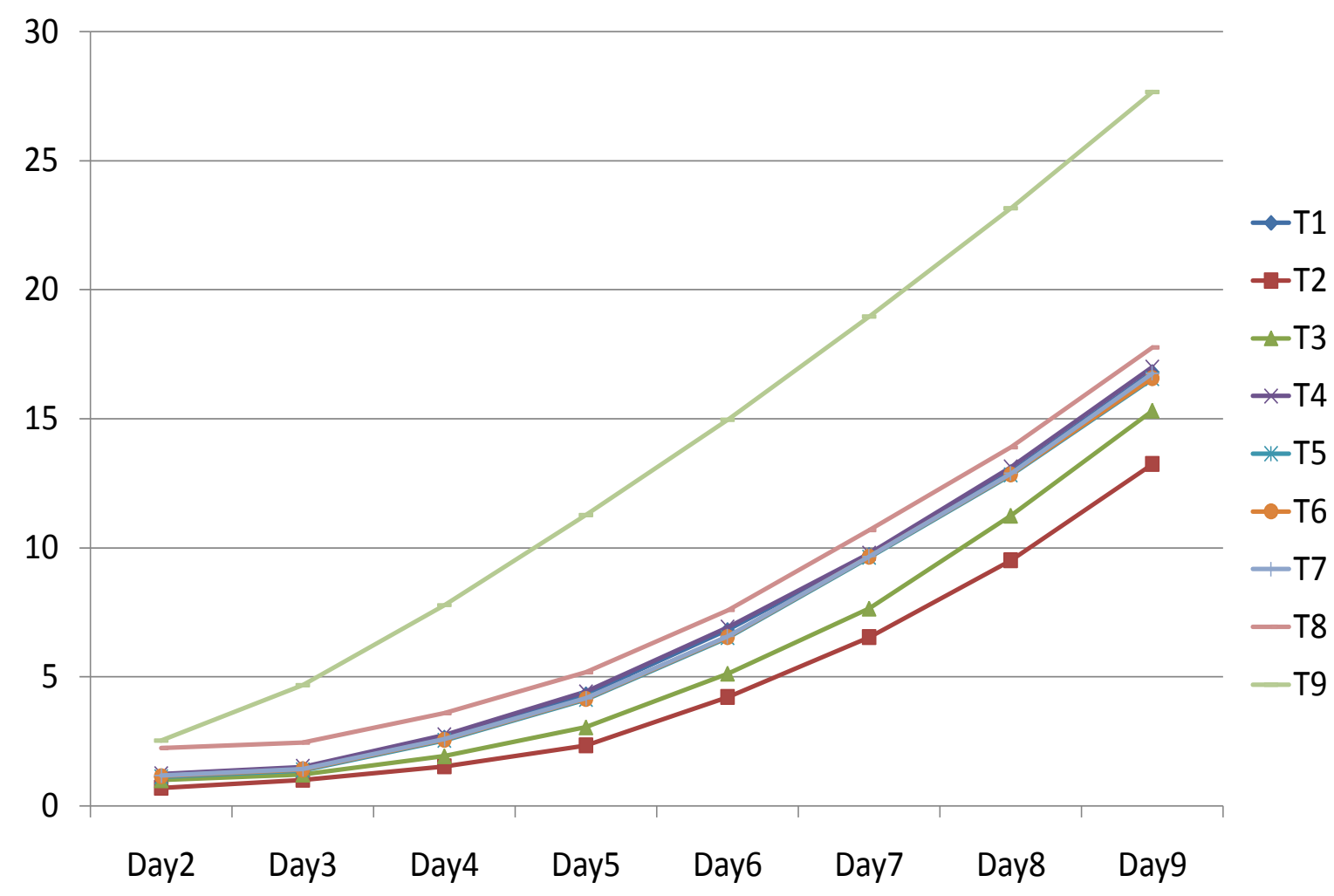

Physiological loss in weight of fruits is mainly due to evaporation of water, respiration and degradation processes occurring during the post harvest handling of fruits (Haard and Salumkhe, 1975). The physiological loss in weight of fruits gradually increased with the storage period has been noticed in guava.

Results revealed that the increase in weight loss was markedly reduced by different pre harvest treatments as compared to control. Among the different pre harvest treatments, lowest PLW was observed with the treatment of calcium chloride $2 \%+$ polythene bag i.e. $3.63 \%$ where as maximum was obtained in control i.e. $13.87 \%$. Maximum shelf life (9 days) was found in treatment of calcium chloride $2 \%+$ polythene bag. Minimum shelf life (4 days) was found in control because of infestation of disease like anthracnose and fruit fly attack.

The increased weight loss of untreated fruits is mainly due to increased storage breakdown associated with higher respiratory rate compared to calcium treated fruits (Faust, 1978). The decrease in PLW by the application of calcium chloride may be due it's role in the maintenance of fruit firmness, reduction of respiration and delay the senescence (Tingwa and Young, 1974; Scott and Wallis, 1977; Singh et al., 1981; Cheor et al., 1990). The pre-harvest treatment of calcium chloride has also been reported to minimize PLW and extend shelf life in mango 
fruits by (Motto 1991; Singh et al.,1993; Singh et al., 1998). Babu and Shanthakrishnamurthy (1993) stated that the mango fruits cv. Alphanso treated with calcium chloride (4\%) as pre and post harvest sprays showed the minimum loss in weight $(12.61 \%)$ as against 18.33 per cent in control. Singh et al., (1998) concluded that the pre harvest spray of calcium compound particularly $\mathrm{CaCl}_{2}$ and $\mathrm{Ca}\left(\mathrm{No}_{3}\right)_{2}$ on mango cv. Amrapali improved the fruit quality and shelf life up to 11 days under ambient condition. Barriga-Tellez et al., (2011) reported that methyl jasmonate and calcium chloride (1\%) application increased shelf life of Guava.

\section{References}

A.O.A.C (2000). Official methods of analysis. 17th edition, Association of Official Analytical Chemists, Washington, D.C. USA

Abbasi, N. A., Chaudhary, M.A., Ali, M.I., Hussain A. and Ali I. (2014) On tree fruit bagging influences quality of guava harvested at different maturity stages during summer, International Journal of Agriculture and Biology, 16 (3): 543-549

Babu, K.H. and Shanthakrishnamurthy (1993). Effect of calcium on physicchemical changes in Alphanso mango during ripening and storage. International Conference Chiang Mai., pp. 390-392

Barriga-Tellez, Leslie Malleli, GarnicaRomo, Guadalupe Ma, ArandaSanchez, Jorge Isidro, Correa, Gabriel Arroyo, Bartolome-Camacho, Maria Carmen Martinez- Flores and Hector Eduardo (2011) Nondestructive tests for measuring the firmness of guava fruit stored and treated with Methyl Jasmonate and Calcium chloride, International Journal of Food Science and Technology.46 (6): 1310-1315

Cheor, F., Wallemot, C., Arul, J., Desjarrdins, Y., Makhlauf, J., Charest, P.M. and Gosselin, A. (1990). Foliar application of calcium chloride delays post harvest ripening of strawberry. $J . A m$. Soc. Hort. Sci., 115: 789-792

Faust, M.(1975). The role of calcium in respiratory mechanism and senescence of apples. Factures et regulation de maturation des fruits. Colloq. Inst. C.N.R.S, 238: 87-92

Haard, N.F. and Salunkhe, D.K.(1975). Symposium on pest biology and handling of fruits and vegetables. The AVI Publishing Co

Jakhar, M.S. and Pathak, S. (2014). Enhancing qualityof mango (Mangifera indica L.) fruits $\mathrm{cv}$. Amrapali with pre-harvest foliar spray and fruit bagging, Annuals of Agri-Bio Research. 19(3): 488-491

Lu, Gui-long; Zhang, Xin-fu; Zhang, Xiaofei; Wang, Ran and Yang, Shao-lan (2014) Effect of pre harvest bagging on the storage characteristics of chilli pear fruits. Modern Food Science and Technology. (No.12): 176-181

Mathooko,F.M., Kahangi, E.M., Runkuab, J.M., Onyangob, C.A. and Owinob, W.O. (2011). Preharvest mango (Mangifera indica L.) cv. 'Apple' fruit bagging controls lenticels discoloration and improves postharvest quality. Acta Hort., 906: 1245-1249

Matoo, A.K., Murata, T., Pantastico, E.B; Ogata, K. and Phan, C.T.(1975). Chemical changes during ripening and senescence. In: Pantastico (ed.) Postharvest physiology, Handling and Utilization of Tropical and Subtropical Fruits and Vegetables. AVI Pub. Co. Inc. P.103-127

Scott, K.J. and Wallis, R.B.H. (1977). Vacuum infiltration of calcium 
chloride: A method for reducing bitter pit and senescence of apples during storage at ambient temperature. Hort. Sci., 12: 53-57

Singh, B.P., Singh, H.K. and Chauhan, K.S. (1981). Effect of post-harvest calcium treatments on the storage life of guava fruits. Indian j. Agric. Sci., 51: 44-47

Singh, B.P., Tandon, D.K. and Kalra, S.K. (1993). Changes in postharvest quality of mangoes affected by preharvest application of calcium salts. Scientia Horticulturae, 54(3): 211-219

Singh, S., Brahmachari, V.S. and Jha, K.K.(1998). Effect of calcium and polythene wrapping on storage life of mango. Indian J. Hort., 55(3):218-222

Tingwa, P.O. and Young, R.E. (1974). The effect of calcium on ripening of avocado (Persia americana Mill) fruits. J. Am. Soc. Hortic. Sci., 99:540542

\section{How to cite this article:}

Swosti Debapriya Behera, Sanjay Pathak and Nishita Pathak. 2018. Appropriate Solution for Poor Shelf Life Problem in Rainy Season Guava (Psidium guajava) var.'L-49'. Int.J.Curr.Microbiol.App.Sci. 7(07): 1792-1798. doi: https://doi.org/10.20546/ijcmas.2018.707.212 